\title{
Urban Land use Characteristics and Trip Generation Patterns in a Developing Economy: A Case Study of Ilesa, Osun State, Nigeria
}

\author{
Adetunji Musilimu Adeyinka. (Ph. D) \\ Department of Geography, Faculty of Arts \& Social Sciences \\ Federal University Lokoja, Kogi State, Nigeria \\ Email: maadetunji@yahoo.com
}

Doi:10.5901/ajis.2014.v3n4p311

\section{Abstract}

There have been many studies on intra city movement in Nigeria but they have not examined the distribution pattern of land use which is central to urban mobility in any country of the world. It is against this background that the study is designed to describe land use characteristics and examine their correlations with household trip flow in a medium sized city of llesa, Nigeria. Primary and secondary sources of data were used for this research. Descriptive and inferential statistics were used to analyze the data. The findings reveal that urban land use in llesa does not comply with the planning regulations. Further analyses reveal that the distribution patterns of urban land use correlate with household travel patterns in the city. The study concludes that there is need to re- design the master plan of llesa and ensure strict compliance with the planning regulations in the city and many other cities in Nigeria as a whole.

Keywords: Urban land uses, GIS, Medium sized city, Land use pattern, Household travel patterns \& Planning regulations

\section{Introduction}

Globally, urban centres are made up of different land uses. These include but not limited to residential, commercial, public, recreational, industrial and circulation or transport land uses. The proportion of land allocated to various land uses, in different parts of the world vary tremendously over time and space depending on their level of development and compliance with the planning regulations. Similarly, the priority for allocation also depends on the use to which the land will be put. For instance, on a typical land use types in Canada, Clark et al (2006) have classified the urban land uses into six categories, with the residential occupying the largest proportion (40\%), closely followed by transportation (32\%), public linstitutional (10\%), open space $(7 \%)$, industrial $(6 \%)$, while commercial land use occupies $(5 \%)$ the least proportion of land use. The urban land use zoning in the advanced countries of the world does not exist in some of the developing countries of the world, most especially in Asian and African countries where mix land use predominated. Many researchers in some of the advanced countries have conducted studies which reveal that there is strong and positive relationship between land use types and household travel pattern (Newman and Kenworth, 1999; Cervero, 2002; Stefano, G. et al 2012). However, studies on the relationship between land uses and household travel behaviors in some of the African countries, most especially Nigeria is very scanty in the literature. The paucity of research on the relationship between land use and transportation is unwarranted for any country striving to achieve a sustainable development in the year 2025. Hence, a detailed study of the distribution patterns of urban land use characteristics will enable the urban geographers, city planners and other stakeholders to fashion out appropriate land use policies for sustainable transport development in urban centres in Nigeria and other similar cities in developing countries of the world. Similarly, some of the urban settlements in African countries most especially in Nigeria have been growing organically without any form of planning and this has adverse effects on household mobility to different activity patterns. The non-compliance with the planning regulations has compounded the mobility problems in some of the cities in Nigeria. It is against this background that this study is designed to examine the land use characteristics in relation to the emerging patterns of movement of urban households in a medium sized city of llesa, Nigeria with the view to promoting sustainable transport development for the cities particularly in Nigeria and in Africa in general.

\section{Study Area}

Ilesa is located on between Latitudes $7^{\circ} 48^{\prime}$ and $7^{\circ} 6^{\prime}$ North of the Equator and Longitudes $4^{\circ} 5^{\prime}$ and $4^{0} 7^{\prime}$ East of the 
Greenwich meridian. The city is the second largest in Osun State after the state capital, Osogbo metropolis. The study area is about 103 kilometres to Ibadan, the defunct regional headquarters of south western Nigeria. It is approximately 534kilometres to Abuja, the Federal Capital Territory (FCT) of Nigeria. The spatial distribution of land use characteristics in llesa shows an interesting pattern. For instance, there are three large markets in llesa. These are Atakunmosa (Oba's market), Irojo and Imo markets. Commercial activities take place at Atakunmosa market fortnightly while transactions at the other two are made weekly by market men and women who come from different locations. Within llesa, there are competing daily trading markets, among which are Adeti, Okesa, Isokun, to mention but few. Besides, there are smaller ones that have grown larger, compared to the time they were established. Similarly, numerous health care providers, which range from specialist hospitals to simple health care spread in different parts of the city. One of such is the Wesley Guild hospital which is located at ljofi in the south eastern part of the city.

In llesa there are Industries that employ hundreds of workers, these include International Brewery, located at Imo along old llesa - Akure road, Yinka Oba Foam, along ljebu-Jesa, Adediran Industry, located along Ife- Akure, Abeobe plastics industry, along llesa- Ife route and AKAD industry located along llesa - Osogbo road. Small scale industries include Ogbedu plastic industry, Doctor Bee water factory and Omuni water factory, many others are scattered in different part of the city. These industries generate a considerable volume of movement between the home of the workers, customers and the industries in the city. Also, the School of Health Technology is located at Bolorunduro along Ife- Akure road. The degree awarding institution, College of Education is located along llesa-Ife road in the south eastern part of the city. The distribution patterns of these tertiary institutions have influenced the pattern of trips to schools by urban youths.

It is the spatial distribution of these socio-economic characteristics described in the foregoing paragraphs that has given the study area its land use characteristics which in turn have influenced the mobility patterns of residents in llesa. There is need to have a comprehensive and proper understanding of land use characteristics in the city so that appropriate land use policy could be designed and complied with in llesa and other cities in Nigeria in the $21^{\text {st }}$ century.
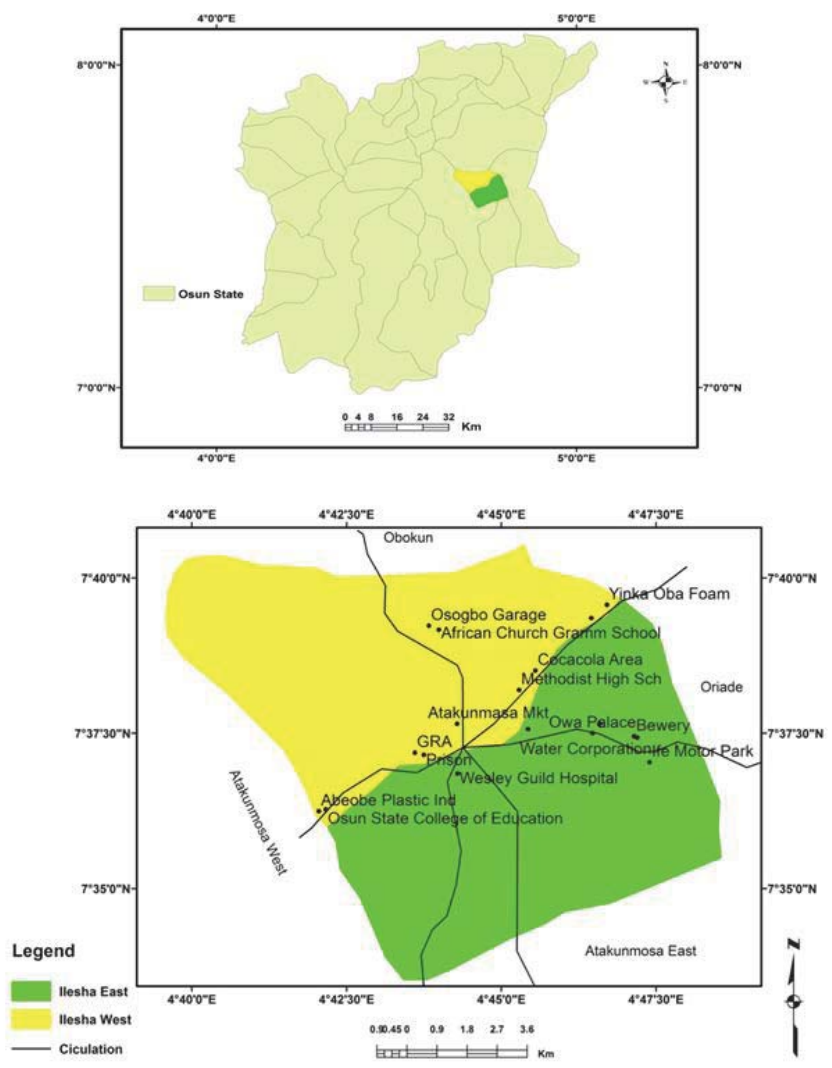

Figure 1: Map of llesa. 


\section{Materials and Methods}

Both primary and secondary sources of data were used for this research. For the primary data, a structure questionnaire was designed to solicit information on the household travel behavior to different land use activities in llesa. An average of sixty copies of the questionnaire was administered in each of the twenty-one political wards that constituted the study area. The questionnaire was administered on the principle of one in every twentieth building along the major road in the city. In a building where more than one household is found, only one head of the household was selected for questionnaire administration. A total of one thousand and two hundred copies of the questionnaire were completed by the households. This was considered to be a good representation of the sample population because it was more than $80 \%$ of the copies of the questionnaire administered for the research.

The secondary data utilized an administrative map of llesa which was used as the base map and a Google image of 2009. The administrative map and Google image were imported into the ILWIS 3.2 Version in TIFF format. The Google image was subsequently enhanced and geo-referenced to enhance visual interpretability and aid the discrimination of features on the image. The image was also registered to the UTM zone 31, Minna datum coordinate system, based on ground control points collected from GPS readings of some selected locations within the study area.

\subsubsection{Land use/Land cover Classification}

The unsupervised method of classification was adopted in this study. This was done because of the highly mixed nature of the Google image pixels which hampers the identification of land use classes. Hence, a map list was created combining the three bands of the Google image. Thereafter, the cluster module of the ILWIS software was used to classify the image into seven clusters which were re-classified into eight land use categories: - Commercial, Cultivation, Industrial, Public, Residential, Vegetation and Water Body as indicated in the Table 1 below:

Table 1: Land use Classification in llesa.

$\begin{array}{lcc}\text { Land use Classes } & \text { Area in Hectares } & \text { Area in Percentages (\%) } \\ \text { Commercial } & 620.27 & 5.70 \\ \text { Circulation } & 1239.96 & 11.39 \\ \text { Cultivation } & 1597.87 & 14.67 \\ \text { Industrial } & 415.65 & 3.82 \\ \text { Public } & 1535.93 & 14.10 \\ \text { Recreational } & 146.15 & 1.34 \\ \text { Residential } & 3535.77 & 32.46 \\ \text { Vegetation } & 1799.61 & 16.52 \\ \text { Total } & \mathbf{1 0 8 9 1 . 2 1} & \mathbf{1 0 0 . 0}\end{array}$

\section{Results and Discussions}

The findings reveal that llesa is one of the ancient cities in Yoruba speaking communities in South-western Nigeria that grows without any form planning regulations, undifferentiated land use patterns predominate in llesa. There are mixtures of different land use activities such as residential and commercial, recreational and residential and public, residential and industrial land uses (see Figure 2 on land use characteristics in llesa). In the last three decades, the state government, through its institutional powers, has enforced a remarkable control over land use policy in llesa and other urban centres within the state. And the study of the analysis shows that eight major land-use types are identified in llesa. These are residential, commercial, industrial, public or utilities and recreational, agricultural, and vegetation land uses 


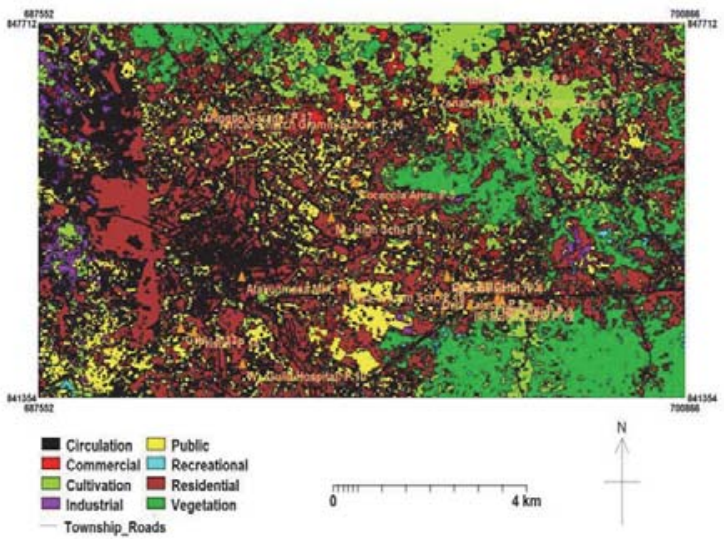

Figure 2: Urban Land uses Classification in llesa

\subsection{Commercial land use}

The commercial land use in llesa covers a total of 620.27 hectares that constitutes approximately $5.7 \%$ of total land use in the city. The main commercial activities in llesa are located at the city centre popularly known as llesa Round About. Also, commercial centres are concentrated along the road sides in the city. This pattern of land use arrangement is similar to old European cities where department stores, markets, retail shops and other commercial activities are concentrated at the central business districts. In recent times, some of the buildings along the road sides in llesa metropolis, that were initially meant for residential units have been demolished or renovated and converted to commercial land use. Further analysis reveals that there are three big markets in llesa, namely, the king's market "Atakunmosa market", Sabo and Imo markets. The Atakunmosa market is a fortnight market, while the other two are weekly markets. These three markets attract more trips from other parts of the city as well as from the neighboring towns and villages in Southwestern part of Nigeria.

Within llesa metropolis, there are three other daily trading markets located in Okesa, Isokun and Adeti which are patronized by the residents and itinerants traders from neighboring towns. The pattern of distribution of market reveals that not all the traditional quarters in the city has a market. These force residents in General Hospital Area, George Burton and Bolorunduro zones to move to other parts of the city for their shopping trips/ activities. The distribution patterns of commercial services generate a considerable volume of trips to some parts of the city where these services are concentrated. Further analysis shows that there is low but positive correlation between household travel behavior and distribution of commercial activities in llesa. The correlation is $r=0.40$ and is significant at 0.01 . The interpretation of this findings shows that urban residents in llesa have access to different commercial centres in the city.

Table 2: Relationship between Household Residential Location and Commercial Centres in llesa.

Correlation

\begin{tabular}{|ll|c|c|}
\hline & & $\begin{array}{c}\text { Geographical Location of } \\
\text { Commercial Centres }\end{array}$ & $\begin{array}{c}\text { Residential Location to } \\
\text { Commercial centre }\end{array}$ \\
\hline \multirow{2}{*}{$\begin{array}{l}\text { Location: Commercial } \\
\text { Centres }\end{array}$} & Pearson Correlation & 1 & $.402^{* *}$ \\
& Sig. (2-tailed) & & .000 \\
& $\mathrm{~N}$ & 1200 & 1200 \\
Residential Location & Pearson Correlation & $.402^{* *}$ & 1 \\
& Sig. (2-tailed) & .000 & 1200 \\
\hline \multirow{2}{*}{ N } & 1200 & \\
\hline
\end{tabular}




\subsection{Residential Land use}

Residential land use occupies a central position in urban space because people live and recreate there. Two types of residential development can be identified in llesa. These are old and new residential buildings. The old residential buildings are found at the city centre. These parts of the city include Ayeso, Oke Eese, ljofi, Okesa, Isokun, Egbedi and Orikiran quarters. Some of the buildings in these parts of the city were constructed with mud blocks more than one hundred years ago. Buildings located at the road sides are used for dual purposes i.e residential in one hand and commercial in another hand which indicates non- compliance with the planning regulations. The old residential buildings in llesa are occupied by indigenous people who are mostly low income earners with large family household size. These zones tend to generate more trips than other zones because of their large family size which require different trip purposes. Burton (1985) argues that one acre of residential land development at a high density would produce more trips than one acre of land developed for residential purposes at a low density area. The road network connecting the residential unit at the core areas of llesa are well tarred with bitumen but they are narrow because some of these routes were constructed before the advent of automobiles in the country.

The new residential structures are found at the outskirts of the city, most especially at Imo, along old llesa - Akure road, Irojo at the western part of the city, George Burton area in the north western part of Ilesa, Coca- cola along ljebu Jesa road and llaje zones along llesa - Osogbo route. Some of the buildings in these parts of the city are relatively modern types and conducive for human habitation. Generally, the well educated people, mostly civil servants and others that have comfortable economic status to travel to different parts of the city for their day to day transactions occupy this zone of the city (Coker 2007; Fadare, 1997).

In all, the land use for residential purpose in llesa covers an approximately 3535.77 hectares, representing about $32.46 \%$ of the urban land use in the city. This is considered to be inadequate, given the high rate of urbanization trends experienced in llesa within the last four decades (Ogundahunsi, 1995). In order to solve the housing problems for low income earners in urban centres in Nigeria, both the federal and state governments established low cost housing scheme in 1985 at the outskirt of the city, particularly along Osogbo road. However, the low cost housing scheme failed woefully in llesa because the construction of the houses did not comply with the culture of the people in the city. Similarly, this low cost housing scheme was located farther away from the built up area of the city. Investigation during the field survey showed that most of the beneficiaries of the scheme were frequently raided by armed robbers. The site however has been re-allocated to individual owners and pockets of immigrants have sprung up in the early part of the year 2011.

\subsection{Industrial Land use}

The industrial land use in llesa covers an average land mass of 415.65 hectares of land in the city and it accounts for $3.8 \%$ of the total land use. The largest industry employing thousands of workers is International Brewery (PLC) located in Imo zone, along old llesa - Akure road. This route witnesses heavy traffic and delay due to road side parking by heavy duty trucks which are waiting to load or off load their goods from the industrial plant. Many of the residents of the area interviewed express their dissatisfaction with the heavy traffic, pollution of different types and unpleasant sound emanating from the industrial plants. The result of this analysis is tangential to what was obtainable in the early 80's in Chicago when vacant industrial land use was developed to residential units as a result of an influx of young urban professionals moving to areas downtown near the industrial corridor to look for white collar job. The resultant effect of this is friction between industrial and residential neighbors which manifest in excessive noise and truck trafficking from the industrial plants (ICIC, 2014).

However, in the later part of the $19^{\text {th }}$ century, the land use zoning in Chicago became more meaningful as the industrial advocates proposed "Planned Manufacturing District," which ensure that land zoned for industrial use is retained in the face of residential and commercial pressure (ICIC,2014). Contrary to what exists in some of the advance countries of the world most especially in Chicago and many other European cities, some of the developers in urban centres in Nigeria, most especially in llesa in the Southwestern part the country are not law abiding citizens, some even develop their residential units without plan approval from the planning authorities which makes it difficult for the planning authorities to enforce strict compliance with the planning regulations in the city and similar urban centres in Nigeria( Ogundahunsi, 1995). Further analysis also reveals that Yinka Oba Foam which employs hundreds of workers is located in the north eastern part of llesa along llesa - ljebu-Jesa route. Adediran Wire and Steel is located along Ife - Akure express route. Abeobe Plastic industry is located in the south western part of the city along llesa- Ife road. Rain Bowl Paints factory and many other small scale industries are scattered in different parts of the city. The distribution patterns of 
these industries in llesa contribute tremendously towards the economic development of the town by providing job opportunities for people. They thus generate considerable volume of trips, especially between them and places where their workers live. It is pertinent to note that the area of land allocated to industrial land use along Osogbo road, Ife road and old llesa - Akure routes have been encroached by residential land use.

\subsection{Recreational Land Use}

Unlike European settlers, ljesas enjoy recreation after the day's work. Even from time immemorial, the ljesa people play different sorts of games to enjoy themselves or sometimes visit friends and relations for their relaxation. Recreational facilities are mixed with residential land use in llesa. Some of the renowned recreational centres which provide good services for their customers include Zenabab Game Resort Centre located along llesa- ljebu Jesa road. This hotel attracts more than twenty thousand tourists annually. Similarly, Amuta and Precious store hotels are located at Irojo zone, Prince way Hotel at Bolorunduro, Concord and Hotel Bee-Hive in George Burton zones in the north western part of the city. These recreational facilities generate considerable volume of trips either within llesa and many other communities in Southwestern Nigeria. The danger posed by the location of recreational centres in the residential area is that many of the unemployed teenagers patronize these facilities to engage themselves in prostitution so as to earn their livelihood. Other recreational facilities which attract large number of youths either within llesa or neighboring towns and villages from the southwestern part of Nigeria include play grounds and cinema houses ( Ogundahunsi, 1995)

In all, recreational facilities in llesa occupy an approximately 146.15 hectares of land which accounts for 1.34 percent of the total land use. This is considered to be inadequate for the recreational needs of over two hundred thousand people in the town, their locations lie mainly in few areas of the city. This implies that a large proportion of the population who live outside these parts of the city have very limited access to the recreational facilities that are provided in llesa. Some of the standard recreational facilities such as hotels and recreational parks located in llesa attract a considerable volume of tourists from different parts of the city and neighbouring communities in southwestern parts of Nigeria. The correlation between the distribution pattern of recreational facilities and household travel pattern is high ( $r=$. 73)

Table 3: Correlation of the Geographical Distribution of Recreational Facilities and Household Travel Patterns in llesa.

\begin{tabular}{|c|c|c|c|}
\hline \multicolumn{4}{|c|}{ Correlations } \\
\hline & & Location of Recreational Facilities & Households Residential Location. \\
\hline \multirow{4}{*}{$\begin{array}{l}\text { Location of Recreational } \\
\text { Facilities }\end{array}$} & Pearson Correlation & 1 & $.730^{* *}$ \\
\hline & Sig. (2-tailed) & & .000 \\
\hline & & 1200 & 1200 \\
\hline & Pearson Correlation & $.730^{*+}$ & 1 \\
\hline \multicolumn{2}{|c|}{ Households Residential LocationSig. (2-tailed) } & .000 & \\
\hline & $\mathrm{N}$ & 1200 & 1200 \\
\hline
\end{tabular}

\subsection{Public Land uses}

The major public land use which attract more than five thousand youths daily in llesa are the Osun State College of Education located along llesa-Ife route and School of Health Technology which is located along Ife -llesa- Akure express road. The propensity of youths to study has generated considerable volume of movement between the residents of youths and locations of schools in the city (Ayeni, 1975). Also, there are more than 40 secondary schools and over 80 primary schools mixed with residential land use in the study area. A similar pattern of land use arrangement occurred in Benghazi, the second largest city in Libya where both private and public primary and secondary schools were scattered throughout the city (http://en.wikipedia.org/wiki/Benghazi?--Already). Table 4 further reveals that the relationship between the pattern of journey to schools by urban youths and the geographical location of educational facilities in llesa shows a high correlation of $(r=0.73)$. Similarly, many health care providers which attract thousands of patients who require health services are scattered in different parts of llesa. These include the General Hospital which is located along the Muroko road in the south western part of the city; and the Wesley Guild Hospital situated at ljofi in the south eastern part of llesa. A critical examination of table 4 shows that the distribution pattern of health care facilities and patients travel behavior 
shows a high and positive correlation of $r=0.73$. Other public land use identified in llesa are llesa East and llesa West Local Government Councils which have employed hundreds of workers living in different parts of the city, they generate more trips from different areas of the city.

Table 4: Correlations between Types of Public Land uses and Household Travel patterns in llesa.

\begin{tabular}{|l|c|}
\hline \multicolumn{1}{|c|}{ Types of Public Land Uses } & Correlation Coefficients \\
\hline Geographical Distribution of Educational Facilities to Household Residential location & $.696^{\star \star}$ \\
\hline Geographical Distribution of Health Facilities to Household Residential Location & $.734^{\star \star}$ \\
\hline Location of Local Government Secretariats to Residential Location. & $.711^{\star \star}$ \\
\hline
\end{tabular}

**.Correlation is significant at the 0.01 level (2-tailed)

Source: Author's Computation, 2013

\subsection{Agricultural / Cultivated Land use}

Unlike any other Yoruba communities located in the tropical rain forest belt of southwestern Nigeria, the principal occupation of ljesa people is farming. Some of the llesa indigenes practice arable farming around their backyards to feed their family and sometimes sell their surplus. They also keep sheep and goats. Also, small and large scale poultry farms are located in different parts of the traditional but economically viable city of llesa with little or no restrictions. However, the land use zoning law in some advanced countries of the world limits the types of animals allowed at a residence, while some ordinances prohibit keeping some types of farm animals in residential neighborhoods for obvious health reasons (http://realestate.findlaw.com/land-use-laws/types-of-zoning.html). In a nutshell, the major cultivated land use in llesa is Levities Foundation located in the eastern part of llesa along old llesa -Akure road which extends to Ife - Akure express road. The land covers an approximately $1 \mathrm{~km}$ length and breadth in the city. With respect to the land use zoning in some of the advanced countries, agricultural zoning ordinances tend to control the minimum lot size for residential structure and sometimes protect farming communities from becoming fragmented by residential development (http://realestate.findlaw.com/land-use-laws/types-of-zoning.html)

\subsection{Circulation Land uses}

The circulation land use in llesa includes urban road network, pedestrian walkways or sidewalks and parks. Some of the urban road networks in llesa do not have pedestrian walkways. The pedestrian walkways that connect Ehindi to ljebuJesa town are narrow and some of the motorists sometimes use it as parking space. The city has no designated bus stops; this probably compounds urban mobility crises experienced in the city early in the morning and late in the evening when the volume of traffic is heaviest. Osogbo Motor Park is located in the south western part of llesa along Oke-omiru road in Ilesa. Passengers whose destinations are Osogbo, Ikirun, Ilorin, Oyo and many other cities in Nigeria usually patronize this park for their trips. Similarly, Odooro Motor Park is the major garage where different vehicles travelling to different towns and cities in south western Nigeria stay for loading and off- loading their passengers and it is located along Ife route. Many other minor motor parks have sprung up in different parts of the city. Even the central business district of llesa is converted to the general motor park early in the morning and late in the evening for passengers travelling to different parts of the country. The circulation land use in llesa covers 1239.96 hectares of land use and accounts for about $11.39 \%$ of the land uses

\subsection{Vegetation}

The outskirt of llesa is surrounded by secondary forest. The vegetation found there is partially cultivated for both cash and food crops. Many of the farmers interviewed claimed that they travel daily to their farm and rely mostly on foot. The total land covered by vegetation in llesa is approximately 1799.61 hectares and this accounts for $16.5 \%$ of the entire land mass in the city. The total hectare of land covered by vegetation in llesa is not static because residential development is encroaching it on daily basis. 


\section{Recommendations}

The study recommends that the planning authorities at the local, state and federal levels should enforce strict compliance with planning regulations for city developers in order to reduce the incidence of conflicts on land use patterns that has characterized the developing cities in Nigeria and other African countries.

There should be public enlightenment on the rationale behind land use zoning in urban centres in Nigeria and other African countries in general. And more importantly, various organizations, religions bodies, developers association, youths and many other stake holders should be educated on how to compliance with land use planning laws in their respective cities as it was done in Chicago in the last two decades.

\section{Conclusions and Planning Implications}

This paper has assessed the characteristics of urban land uses in a medium sized city of llesa in south western part of Nigeria. Both primary and secondary sources of data were used for this research. Using descriptive and inferential statistics, the findings reveal that the traditional city of llesa is characterized by undifferentiated land use patterns. There is a mixture of residential/ industrial, commercial/ residential, public / residential land uses. The patterns of land use in the city do not comply with the planning regulations. The residential land use in llesa shares the highest proportion of land use in the city. Further analysis shows that the distribution pattern of land use in llesa correlates greatly with households travel behavior. The study concludes that there is the need to redesign the master plan of the city and enforce households' strict compliance with the planning regulations before embarking on further developmental structure in the city.

\section{References}

Adeniji, .K. (2000): Transport Challenges In Nigeria in the next Two Decades Monograph Ibadan. Nigerian Institute of Social and Economic Research (NISER), Transport Studies Units.

Ayeni, M.A.O. (1975): Some Determinants of The Propensity To Interact In An Urban System. A case study of Jos, Nigeria. Nigerian Geographical Journal, vol. 18 No. 2 pp. 111-120.

Burton, M.J. (1985): Introduction to Transportation Planning 3rd Edition London: Hutchinson.

Cervero, R and Kara, K. (1997): Travel demand and 3 Ds: Density, Diversity and Design. Transport Research D, Vol. 3 PP.199-219

Clark, Bruce W. et al (2006): Making Connections: Canadian's Geography. Second edition. DonMills, ON: Pearson Education Canada inc.2006. p. 245

Cooker, A. O; Awosika, S.O Olomolaiye, P.O and Booth C.A (2007): Challenges of urban housing quality and its Associations with neighborhood environments: Insight and experiences of Ibadan city, Nigeria. Chartered institute of environmental health, vol. 7 Issue 12007

Fadare S.O. (1997): Urban Sprawl and Trip Length Characteristics in Ibadan, Nigeria. Ife Planning Journal, vol.1 No.1 Pp. 55-69.

Find Law (2013): Types of Zoning. Available online: http: realestate.findlaw.com/land-use-laws/types-of-zoning.htm.

Initiative for a Competitive Inner City Insights (2014): Protecting Chicago's Industrial through Planned Manufacturing Districts. Available online at http:www.icic.org/connection/blog-entry/lbp-protecting-Chicago-ind

Newman, P. Kenworthy, J. (1999) :" Automobile Dependence and Urban Form", wwwistp. Murdoch.edu. Au publications/ projects Jan/ $\mathrm{pdf} / \mathrm{ch} 8 \mathrm{pdf}$

Ogundahunsi, D.S (1995): An Assessment of Development Control in llesa Local Government, Osun State. An Unpublished M.Sc. Thesis, Department of Urban and Regional Planning. Obafemi Awolowo University, lle - Ife. Pp131

Okoko, E. (2008): Urban Transportation Planning and Modelling". Millennium Publishers. Akure ,Nigeria.

Peel, J. D. Y (1983) ljesa and Nigerians. The incorporation of a Yoruba Kingdom 1890s-1970. Cambridge University Press, Cambridge. London. Pp333.

Stefano Gori; Marialisa Nigro \& Marco Petrelis (2012): The impact of land use characteristics for sustainable mobility: the case study of Rome. European Transport Research Review. (2012) 4: 153-166 http://en.wikipedia.org/wiki/Benghazi?--Already 